\title{
SYMPOSIUM: Schooling in Capitalist America
}

\section{Editor's Note}

This symposium originated as one session of the annual (joint national-regional) meeting of the History of Education Society, held October 23, 1976 at the Gutman Library, Harvard University. This series of essay, commentaries, and replies represents a reconstructed transcript of that symposium session.

The focal point of the symposium was the new book, Schooling in Capitalist America by Sam Bowles and Herbert Gintis. In the preparation for publication, Professor Cohen's initial comments have grown well beyond his actual remarks that day. The editor encouraged him to publish this more refined statement of his views and now urge the readers, especially those yet unfamiliar with the book under discussion, to take advantage of Professor Cohen's introduction to the issues Bowles and Gintis have raised.

The editor would like to extend special thanks to Professor Michael Olneck of the University of Wisconsin who made the original tape of the symposium available to the History of Education Quarterly.

P.H.M. 